\title{
Ocular Adnexal Lymphoma Clinical Distant Metastasis TNM Finding v7
}

National Cancer Institute

\section{Source}

National Cancer Institute. Ocular Adnexal Lymphoma Clinical Distant Metastasis TNM

Finding v7. NCl Thesaurus. Code C88859.

A clinical finding about one or more characteristics of ocular adnexal lymphoma,

following the rules of the TNM AJCC V7 classification system as they pertain to distant metastases. 